\title{
Integrative Research Paper: Swiss Executive Pay Referendum
}

\section{Abbott Haron*}

Faculty of Higher Colleges of Technology, Swiss Management Center University, Sharjah, United Arab Emirates

\begin{abstract}
This paper provides an account of the specific provisions contained in the new resolution. Furthermore, the paper examines the pros and cons of the Swiss new law on executive compensation in light of recent corporate governance advances. In March of 2013, Swiss voters were asked whether they supported a federal order on family policy, a modification to the federal law on spatial planning, and a popular initiative on executive pay, which would introduce compulsory shareholder votes on salary levels, in addition to banning golden hellos for new employees and golden parachutes for departing staff. However, we need to warn that the binding say-on-pay is not a magic potion. This is because influential shareholders are likely to influence opinion for executive pay plans that further shareholders narrow interests at the disadvantage of key voters in the company, including less prevailing shareholders, employees, and debt holders.
\end{abstract}

Keywords: Referendum; Swiss executive

\section{Introduction}

In view of the number of high-level corporate scandals, leading up to the global financial meltdown starting in 2007, In March 2013, the citizens of Switzerland voted in a national referendum to place new limitations on executive pay within the country. This paper provides an account of the specific provisions contained in the new resolution. Furthermore, the paper examines the pros and cons of the Swiss new law on executive compensation in light of recent corporate governance advances. We make a case that this referendum could transform the power structure in the boardroom, by de-institutionalization pays that pertains to powerful CEO's of Swiss companies. However, take care that while a binding vote may possibly bring about a major revolution in the executive pay setting, it may not produce the desired worldwide cure. This is since powerful stockholders are likely to influence opinion for executive pay plans that further shareholders narrow interests at the hindrance of key communities in the corporation, including less dominant shareholders, as well as other stakeholders. Being an important element of corporate governance, executive compensation should persistently attempt to blend the incentive packages of senior executives with shareholders rights [1].

\section{The Swiss Referendum}

In March of 2013, Swiss voters were asked whether they supported a federal order on family policy, a modification to the federal law on spatial planning, and a popular initiative on executive pay, which would introduce compulsory shareholder votes on salary levels, in addition to banning golden hellos for new employees and golden parachutes for departing staff. The family policy question was approved by a majority of voters, but rejected by a majority of districts. The planning question was approved by a majority of voters and did not need a district majority. The executive pay initiative was approved by approximately two thirds of voters and all districts [2].

According to [2] approving the executive pay initiative, Swiss voters implemented some of the world's harshest limits on executives' pay in the referendum; a change critics say could make Switzerland less attractive to international corporations. The initiative proposed by Thomas Minder head of a Swiss herbal toothpaste company, was supported by 67.9 percent of the voters, the Swiss government said on its website. The turnout was 46 percent of the Swiss voting population (Table 1).

Thomas Minder created the proposal and launched the campaign when in 2008 following major losses at UBS, which were blamed on a bonus culture leading to extreme risk taking by executives. The Swiss government would amend legislation to:

- Require a once a year vote by stockholders for the president and other members of the board of directors, members of the compensation committee, and any advisory board and executive officers of the organisation.

- Necessitate the articles of association to include bonus systems and pay plans for managers and executive officers, any loans approved to such employees, the number of directives outside the organisation, and the length of employment contracts of executive officers.

- The ban of advance and severance packages.

- The ban of corporate delegation and the representation of shareholders by a collection of banks.

- The requirement of retirement funds to disclose the way they vote, and to vote in the interests of pension policyholders.

According to Minder [3], Mr. Minder initiated his campaign after his family owned business came close to insolvency. The business had been a provider of toothpaste and other body care products to Swissair, which was grounded in October 2001. Earlier that year, the airline paid 12 million Swiss francs to a new CEO, Mario Corti, who then left soon after the carrier's demise. Mr. Minder widened his campaign against excessive compensation, critical of several bankers and other prominent managers of receiving "rip off" pay packages. His campaign increased in momentum that relatively few managers would oppose him openly. Still, Nestle, the food company based in Switzerland, was among his enduring adversaries.

The subject of executive compensation is contentious. Executive compensation is viewed as an answer to align the benefits of owners with those of managers. However, instead of resolving the problem,

*Corresponding author: Abbott Haron, Faculty of Higher Colleges of Technology, Swiss Management Center University, Sharjah, United Arab Emirates, Tel: 065054-418; E-mail: abbott.haron@hct.ac.ae

Received December 05, 2014; Accepted December 20, 2014; Published December 30, 2014

Citation: Haron A (2014) Integrative Research Paper: Swiss Executive Pay Referendum. Int J Econ Manag Sci 4: 218. doi:10.4172/2162-6359.1000218

Copyright: () 2014 Haron A. This is an open-access article distributed under the terms of the Creative Commons Attribution License, which permits unrestricted use, distribution, and reproduction in any medium, provided the original author and source are credited. 


\begin{tabular}{|c|c|c|c|c|c|c|c|c|c|c|c|c|}
\hline \multirow{2}{*}{ Question } & \multicolumn{2}{|c|}{ For } & \multicolumn{2}{|c|}{ Against } & \multirow{2}{*}{$\begin{array}{l}\text { Invalid/ } \\
\text { blank }\end{array}$} & \multirow{2}{*}{$\begin{array}{l}\text { Total } \\
\text { votes }\end{array}$} & \multirow{2}{*}{$\begin{array}{l}\text { Registered } \\
\text { voters }\end{array}$} & \multirow{2}{*}{ Turnout } & \multicolumn{2}{|c|}{ Districts for } & \multicolumn{2}{|c|}{ Districts against } \\
\hline & Votes & $\%$ & Votes & $\%$ & & & & & Full & Half & Full & Half \\
\hline Executive pay & $1,616,184$ & 67.96 & 761,975 & 32.04 & 40,666 & $2,418,825$ & $5,174,680$ & 46.74 & 20 & 6 & 0 & 0 \\
\hline
\end{tabular}

Table 1: Referendum results.

the pay mechanism exacerbates the agency problem. Though there is an upward tendency in the salaries of managers, additional money paid to executives does not ensure high returns to stockholders as Ergin [4] would argue.

According to Ergin [4], the conflict of interest between stockholders and managers has been known long before. He argued that executives must be controlled in order to evade losses. In addition, managers cannot watch partner's money with the same watchfulness with which partners watch over their own so the disregard and excess, therefore, must always triumph in the management of matters of a company. The pay mechanism is considered one of the approaches to reduce this conflict of interest. Nevertheless, executive compensation has become a provocative issue, as pay-for-performance relation is vague [4]. The salaries and bonuses of Forbes $800 \mathrm{CEO}$ increased from an average of $\$ 700.000$ in 1970 to over $\$ 2.2$ million in 2000 [4]. The upsurge continued until 2008 when the global financial crisis started. This tendency is partly explained by the "fat cat" theory used by the media. A similar theory explains that executives with power, also known as "entrenched CEOs", use captive board of directors to organize for themselves large increases in pay at the expense of corporations' shareholders [5].

In the author's humble opinion, this type of referendum is historical in every sense of the word; it tries to tackle the obvious asymmetry between what the shareholders and owners of a company want to achieve and what the executives want for themselves. In addition, as demonstrated by the reason why Mr. Minder initiated his campaign after his family owned business came close to insolvency because of the exorbitant package paid to the Swissair CEO months before it collapsed. Another piece of evidence is apparent in the study below that proves that there is not strong correlation between high compensation packages and high company performance.

The research study conducted by Ergin [4] shows quantitatively the weak link between high compensation and high performance. Table 2 presents descriptive statistics of executive compensation (EC) and market value (MV) as well. All figures are in Turkish Liras (TL) and are to be multiplied by 1.000 .

The typical firm market value was TL9.554.323, the typical book value was TL5.574.850 and the typical net income was TL1.039.067. The results indicate that the sampled companies are comparatively important ones in the Turkish market. The typical executive compensation is TL20.295 where the minimum is TL881 and the maximum is TL100.075.

\begin{tabular}{|l|c|c|c|c|c|}
\hline \multicolumn{7}{|c|}{ Descriptive Statistics } \\
\hline Variables & Average & Std.Dev. & Median & Minimum & Maximum \\
\hline MV & 9.554 .323 & 10.309 .391 & 3.080 .000 & 436.000 & 34.320 .000 \\
\hline BVE & 5.574 .850 & 5.670 .654 & 1.941 .667 & 435. & 18.986 .655 \\
\hline $\mathrm{NI}$ & 1.039 .067 & 1.108 .709 & 268. & 3. & 3.401 .986 \\
\hline LN(EC) & 9,4 & 1,0 & 9,5 & 7. & 12. \\
\hline EC & 20. & 22. & 13. & 881 & 100. \\
\hline
\end{tabular}

Note: $n=42 . M V$ is the market value of the firms quoted on Istanbul Stock Exchange. BVE is the book value of equity. NI is the net income. $L N(E C)$ is the natural logarithm of the executive compensation (EC). All of the value are in Turkish currency and are to be multipled by 1.000 .

Table 2: Descriptive Statistics [4].
Table 3 shows the Pearson correlations among test variables. The largest and significant connections are between MV, BVE and NI variables. Management compensation has a negative association with market value and is not statistically correlated with other variables. This shows a negative relationship.

When the management compensation increases, experimental results show that the wealth of shareholders is transferred to management, producing a negative impact on the share price. In the study of agency theory one can see that agency theory predicts that managerial pay is positively correlated to firm performance, however, the empirical results fail to establish a positive association. "Entrenched executives" and the absence of compensation committees to formulate an optimum contract are the likely answers for this negative relationship. The board of directors should revamp the executive compensation system to maximize shareholders' value (Table 4).

To discuss the pros and cons of such a referendum, one must understand that everybody dreams of making big money. However, there can be drawbacks to drawing a large salary, and we are not just talking about the higher marginal tax rate.

For one thing, those with the largest pay-cheques are subject to intense public examination. Contemplate the case of Chris Eagle, the former president of Alberta Health Services, in Canada. He stepped down amidst controversy after some homecare clients who were denied service due to difficulties with contracted suppliers in Edmonton. Nevertheless, latest headlines aside, much was made of his $\$ 580,000$ base income. One of challenges with public sensitivity around compensation is that people's personal perception of what 'big' is, may not be aligned with what the market truths are. So while the average Canadian can't even envisage what it's like to take home more than half a million dollars a year, salaries like those of Eagle aren't necessarily out of line in the big picture. In fact, many of his counterparts in other countries make multiple times what he makes [6]. And if or when things go wrong or when the economy tanks the way it did in 2007-2008, those with the massive take-home pay are frequently walking targets.

\begin{tabular}{|c|c|c|c|}
\hline \multicolumn{4}{|c|}{ Correlation Between Variables } \\
\hline Variables & BVE & NI & LN(EC) \\
\hline MV & $0.802^{*}$ & $0.800^{*}$ & -0.118 \\
\hline BVE & & $0.855^{*}$ & 0.009 \\
\hline NI & & & 0.205 \\
\hline
\end{tabular}

Note: $n=42 .{ }^{*}$ represents significance at the $0.1 \%$ level (one tailed test). Table 3: Correlation between variables [4].

\begin{tabular}{|c|c|c|}
\hline & Models & \\
\hline Variables & Model 1 & Model 2 \\
\hline BVE & $1.25^{*}$ & $0.81^{* * *}$ \\
\hline $\mathrm{NI}$ & $4.14^{* *}$ & 5.98 \\
\hline LN(EC) & - & $-0.82^{*}$ \\
\hline Constant & -0.55 & 7.48 \\
\hline Adjusted R3 & 0.84 & 0.86 \\
\hline F-Statistics & 57.48 & 36.55 \\
\hline
\end{tabular}

Note: ${ }^{*},{ }^{* *}{ }^{* * *}$ represent significance at the $1 \%, 5 \%$, and $10 \%$ levels, respectively. Table 4: Models [4]. 
Another major con of this referendum is the result is the "negative signal for Switzerland as a place for doing business", Economiesuisse, who are a business lobby which had campaigned against the proposal, said in a statement the day of the referendum. Nestle chief executive Bulcke said that, Mr. Minder's plan will make Switzerland a less attractive country for international corporations and executives [2]. "I hope it doesn't pass, I don't think it's good for Switzerland at all," ABB chief executive Joe Hogan said in an interview. He argued that for international corporations like $\mathrm{ABB}$, they have to attract and retain the best talent in the world, and if the referendum is passed successfully, it will inhibit their ability to attract some of the worlds most talented CEO's [7].

Many argued that one of the most significant reasons for Switzerland's success has been the autonomy its corporations enjoy to negotiate pay locally, acclimatizing to significant differences in the living standards of its 26 districts. Adopting the proposed referendum would mean imposing restrictions at national level for the first time, setting what many believe would be a hazardous precedent which can harm the Swiss economy [8].

\section{Swiss Voters' Rejection of the CEO 1:12 Pay Cap Initiative}

One wonders whether well-paid CEO's are part of a secret order with special handshakes and interweaving links into government, homeland security and the gods. How else can one explain their ever-increasing pay packages without the workers they boss or the stockholders they serve revolting?. If there is such a group The CEO of The Warehouse company Mark Powell might have just been expelled for giving the game away and bad mouthing his fellow members. In a recent interview, he confessed to being embarrassed by his $\$ 1.7$ million compensation. "All CEOs should be concerned by how much they earn", he said [8].

Defenders of CEO salaries point out their pay are a portion of the value added for stockholders [6]. This is sometimes true, and occasionally the odd managing director can make a real difference, nevertheless many CEO heroes are often shown to be pretenders in the end. Some benefit from economic tail-winds or short-termism when receiving initial glory. Others have taken corporations to the edge.

The Swiss people rejected a proposal to limit the salary of CEO's to 12 times that of their lowest-paid workers, following a considerable campaign by big business that spent millions in advertising against the measure [9]. The proposal was opposed by 65 percent of voters. The vote on the so-called "1:12" initiative came after Swiss voters accepted the so-called fat-cat proposal in March of the same year, which allocates the stockholders a binding vote on top managers' salary and obstructed extra compensation such as the severance pay. Presented by Young Socialists, supporters of the "1:12 initiative" claimed that imposing a limit on earning would create more transparency and greater equality [9]. Opponents on the other hand said that such a move would harm the country's economy, which heavily depends on its banking sector. They argued that imposing a wage cap would destroy Switzerland's competitiveness and drive out transnationals, as they would not be able to offer high salaries for the world's most talented executives [9].

The corporate 'fat-cats' in Switzerland have poured big money to influence the result of the referendum and succeeded according to Ewing [9]. Followers of the bill said the public relations campaign in pre-poll period was beaten by a 1 to 40 difference with 200,000 Swiss Franc paid by the organizers of the campaign and 8.8 million Swiss Franc by the companies and legislators opposing it [9]. Basically, they did not have a chance, you might consider the author to be a bit of a pessimist, however, we believe that whatever the supporters of this proposal would have done, it would have still been defeated, and even if it have passed, they would have found loopholes in the legislation to keep doing what they always have. The reality is that governments and society are reactive instead of being proactive and as long as money mixed with politics, there will always be an incentive to bend the rules. We would have obviously voted in favor of such proposal as a matter of principle, nevertheless, we know quite well that very little will change. Humanity will eventually deal with these injustices when we are on the edge of losing everything or after the next great depression; the best lessons in life are the hardest.

The Swiss debate about executive pay became amplified when the drug group Novartis agreed to pay its outgoing chairman, Daniel Vasella, a $£ 49$ million 'golden gag' to stop him from working for another competitor. The so-called 1:12 campaign is part of a wider drive for wealth reallocation by the Swiss left that has won wide popular support. Long-standing reverberations about executive excess were driven by the banking crisis and the dangerous position of the Swiss bank UBS. Nevertheless, there followed a massive public and political reaction, with the Swiss justice minister, Simonetta Sommaruga, saying the payoff was "a huge blow to the social cohesion in our country" and payments on such scale "undermined public trust in the entire economy". Novartis were forced to scratch the payout. However, grave damage was done, and in a referendum the following month, more than two-thirds of Swiss voters supported a new regulation to ban golden hellos and goodbyes. However, many Swiss were uncomfortable with an inflexible, government-imposed salary cap. Switzerland, one of Europe's most business-friendly countries, conventionally forces light regulation on business and has comparatively low income taxes. Partly as a result, the country is a popular base not only for banks and hedge funds, which have massed in Geneva, but also key chemical, pharmaceutical and machinery companies.

An absolute salary cap was considered too risky for most voters, said Daniel Kübler, an associate professor of political science at the University of Zurich, "People have concerns about the way modern capitalism works, but they still prefer a free-market economy," Mr. Kübler said.

Parliament voted not to recommend the proposal, as did the Federal Assembly, the seven-member board that governs the country. The assembly said it identified with the sentiments behind the initiative but dreaded it would drive away business and be difficult to enforce. Although the referendum was beaten, voter disappointment at the behavior of some Swiss corporations and executives is prevalent. Advocates of the initiative complained that corporations like the Swiss banking giant UBS, which received a government bailout because of the financial disaster of 2007, continued to pay managers enormous bonuses even when they performed poorly [5].

There are four main reasons why people and governments (like the US and England) are trying to control the explosion in compensations of executives, and they are; to control the cost of compensation, to attract and retain the right executives, to motivate the right executive performance and to present the right optics concerning executive compensation to key organizational shareholders. Each of these merits separate attention [10].

\section{Control the Cost of Executive Compensation}

Executive compensation is a business cost, and as such, it is 
appropriate to try to place it at a cost level that is "reasonable" and "competitive." There is good reason to believe that executive compensation in many corporations is too high by some reasonable standards. For example, some companies have pay levels that are out of line with the U.S. market for executive compensation and decrease corporate earnings accordingly. It is also true that executive pay levels in U.S.-based companies are higher than that elsewhere in the world. This is particularly true in large companies. As a result, U.S.based companies have higher executive salary costs than their offshore competitors (Table 5).

\section{Attract and Retain the Right Executives}

Possibly, the most important thing that an effective executive compensation plan can do is to attract and retain the precise type of executives. Two features of any compensation package influence attraction and retention: its total amount and what forms of compensation are in it. Obviously, the greater total amount of compensation, the more attractive a compensation package is to an executive. The features of the plan-that is, whether it pays-out in stock, cash, short-term or long-term, have a big impact on attraction and retention. Deferred compensation and long-term pay plans can be potent retention devices, although they may not be highly effective in recruiting high-ranking executives. Stock options, stock grants, and bonus plans can be particularly powerful retention devices if the corporation performs well [10].

\section{Motivate Performance}

Perhaps the most complex area when it comes to executive compensation is motivation. In some respects, the way compensation affects motivation is comparatively simple and forthright. When all is said and done, people tend to be motivated to perform in a particular way when they are compensated for performing in that way. How motivated they are is very much a function of how clear the link is between performance and reward, and, of course, how large the reward for performance is. This very rationale has led to large bonus payments for executives and very large stock plans [10] (Figure 1).

\section{The Right Approach}

The scorecard with respect to the likely impact of government directive of executive compensation is not promising. This raises the question of whether there is a better substitute, and we think there is. Executive compensation is the responsibility of corporate boards; they need to do a better job, but are unlikely to unless governance modifications are made. The research of Lawler [10] shows that $31 \%$ of board members think CEO pay is too high in most cases; another $47 \%$ feel it is too high in a few prominent cases. These feelings are doubtful

\begin{tabular}{|l|l|l|l|l|}
\hline \multicolumn{5}{|c|}{ CEO Financial Fortunes Drop AcrossMajor Industries in 2008} \\
\hline & $\begin{array}{l}\text { Aggregate } \\
\text { 2008decline } \\
\text { (\$In millions) }\end{array}$ & $\begin{array}{l}\text { CEO median } \\
\text { decline } \\
\text { (\$In millions) }\end{array}$ & $\begin{array}{l}\text { CEO median } \\
\text { \% decline }\end{array}$ & $\begin{array}{l}\text { Median 1-Year } \\
\% \text { Total Return } \\
\text { to Shareholders } \\
\text { (TRS) }\end{array}$ \\
\hline Healthcare & $-\$ 202$ & $-\$ 13$ & $-24 \%$ & $-17 \%$ \\
\hline Technology & -5.056 & -30 & -38 & -26 \\
\hline Consumer & -294 & -25 & -45 & -27 \\
\hline Materials/industrials & -1209 & -42 & -59 & -40 \\
\hline Financial Services & -3.192 & -95 & -76 & -68 \\
\hline Energy/Utilities & -3.443 & -183 & -58 & -47 \\
\hline All Industries & -13.396 & -39 & -53 & -40 \\
\hline
\end{tabular}

Table 5: CEO Compensation [10].

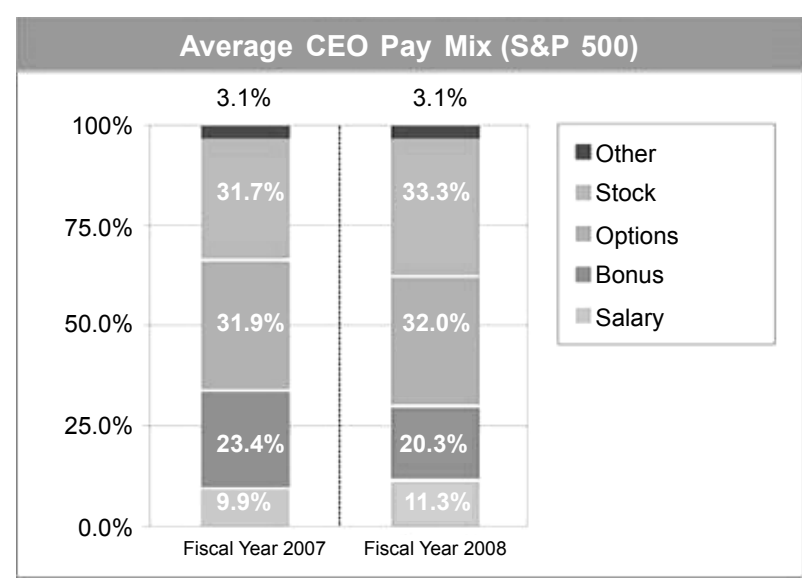

Figure 1: Average CEO Pay mix [10].

to lead to action, however, since $85 \%$ feel their corporations' CEO pay program is effective. However, two key governance alterations might lead to boards creating more effective executive compensation plans.

The first necessitates that all boards separate the role of CEO and board chair. This is common in Europe and it may not be unintentional that compensation levels are much lower in Europe. In Europe, however, the chair is often a previous CEO of the company and cannot be labeled as an independent chair. In order to have an effective chair, the chair must be independent of the company and its managers. This is more likely to lead to a board that makes tough resolutions about how executives are paid [11].

The second change is putting executive compensation plans to a vote of the shareholders, for whom the CEO and top executives ultimately work. Because shareholders are "the boss," they are the logical ones to determine CEO compensation. A first step, which has been taken by less than a dozen major companies, is to make the vote advisory. If this does not constrain CEO compensation, then it is important to move on to a mandatory shareholder vote on all top executive compensation plans [5].

Finally, there is an opportunity that by moving now to reduce executive compensation levels and advance corporate governance, CEOs and boards can avoid additional government regulation of executive compensation [12].

\section{Conclusions}

Forcing corporations to present their executive pay and compensation policies to a shareholder's vote, and a binding sayon-pay regulation, officially launches shareholders into the decisionmaking process, which beforehand was bestowed onto the members of the board. The intent of this paper has been to show whether a binding say-on-pay policy can find the underlying cause of executive pay and compensation shortfalls, which in our opinion are coming largely from conferral of extreme power on the chief executive officer as well as problems related to the flow of information in the boardroom. The enhancement of shareholder participation in the remuneration and compensation process would most likely trimdown compensation inadequacies. More specifically, shareholders can impart a counterbalance to influential and entrenched chief executive officers and in that way moderate the chief executive officer's control over remuneration activities. The contributions of shareholders during 
the remuneration setting process improve the information climate of the board of directors, thereby, serving to trim down information flow shortages.

However, we need to warn that the binding say-on-pay is not a magic potion. This is because influential shareholders are likely to influence opinion for executive pay plans that further shareholders narrow interests at the disadvantage of key voters in the company, including less prevailing shareholders, employees, and debt holders. Furthermore, board of directors' that desire to put in place faulty and not good enough remuneration plans can deal with executive compensation revelations in such a way that the revealed remuneration strategy is seen to align with the interests of shareholders. Therefore, shareholders are hesitantly and unlikely to depose sub-optimal remuneration through the binding say-on-pay policy. Likewise, suboptimal remuneration that has secured genuineness from a passing binding say-on-pay vote is tricky to amend and will probably still be around.

\section{References}

1. Beck A (1989) Company Law: Minority Shareholders and Allotments for an I. Australian Business Law Review 17: 321.
2. Bosley C (2013) Swiss Voters Approve Limits on 'Fat Cat' Executive Pay

3. Minder R (2013) Switzerland votes to limit executives' pay packages: Passing by large margin, referendum places power in shareholders' hands. International Herald Tribune. Paris, France.

4. Ergin E (2013) Does Excessive Executive Compensation Really Pay Shareholders? Academy of Accounting and Financial Studies Journal 17: 47-56.

5. Monks RA, Minow N (2011) Corporate Governance. John Wiley \& Sons

6. Faria P, Martins FV, Brandão E (2013) Executive Compensation: Pay-forPerformance in High-Technology Firms. China-USA Business Review 12: 1072-1083.

7. Winters P, Schaper EV (2013) Fat-Cat Pay Makes Swiss So Mad Wages Face National Vote.

8. Hooper J (2013) Swiss divided as 1:12 executive pay referendum nears. The Guardian.

9. Ewing J (2013) Swiss Voters Decisively Reject a Measure to Put Limits on Executive Pay. The New York Times. Frankfurt: The New York Times.

10. Lawler EE (2009) Fixing Executive Compensation: Right Time, Wrong Approach.

11. Pande S, Ahmad VA (2014) A Theoretical Framework for Corporate Governance. Indian Journal of Corporate Governance 7: 56-72.

12. Jo H, Harjoto MA (2011) Corporate Governance and Firm Value: The Impact of Corporate Social Responsibility. Journal of Business Ethics 103: 351-383. 